\title{
74 editorial fiction and theory: crossing boundaries
}

In this issue of Feminist Review, feminist literary critics consider possible accommodations between post-modernist and humanist conceptions of identity. The essays discuss a wide variety of texts from a turn of the century Australian popular romance, to a 20th century Indian novel. They explore the viability of retaining female agency in revised versions of self-hood, while simultaneously accepting that identity is always constructed in language, provisional, and the outcome of complex intersections of 'race', ethnicity, class, gender and sexuality. The articles revisit crucial questions about the relationship between gender and writing, and writing and the body. Themes linking the pieces include transgender, autobiography, androgyny and aesthetics.

Tracy Hargreaves explores the contours of identity through the discontinuities of dominant sex/gender systems. In Jackie Kay's novel Trumpet, she identifies a complex balancing of the need to claim identity and a post-modern awareness of the subject in process. This is also a theme developed in Nicky Marsh's piece on Lyn Hejinian's experimental Language poetry. Margot Canaday's discussion of Nancy Fraser and Seyla Benhabib shifts the focus from the literary to the theoretical realm, while Ashwarya Lakshmi gives a postmodernist reading of the language of Sati.

Both Nicky Hallett and Tanya Dalziell argue that female sexuality - whether lesbian or heterosexual - is the transgressive force in the texts they discuss. The broader question of the political efficacy of literature is raised in Hallett's piece and taken up again in Loraine Day and Lyn Thomas's discussion of the controversial contemporary French writer, Annie Ernaux.

\section{Helen Crowley, Lyn Thomas, Vicki Bertram}

doi:10.1057/palgrave.fr. 9400099 